第 1 表 製品品質の例

\begin{tabular}{|c|c|c|c|c|c|}
\hline & $\mathrm{Ta}_{2} \mathrm{O}_{5}$ & $\mathrm{Nb}_{2} \mathrm{O}_{5}$ & $\mathrm{Fe}_{2} \mathrm{O}_{3}$ & $\mathrm{SiO}_{2}$ & $\mathrm{TiO}_{2}$ \\
\hline 酸化タンタル $\mathrm{A}$ & - & 0.0010 & 0.0007 & 0.0010 & $<0.0010$ \\
\hline " B & - & 0.0090 & 0.0015 & 0.0090 & $<0.0010$ \\
\hline 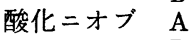 & 0.0050 & - & 0.0008 & 0.0010 & $<0.0010$ \\
\hline , & 0.0090 & - & 0.0018 & 0.0080 & $<0.0010$ \\
\hline
\end{tabular}

し，今までに加えて“より安く”供給するという責務をも自らに 課したものである。

コストダゥンで最も効果的な方法は増産, 増販による固定費単 価の引下げである。これはユーザー各位における S R E 関連商品 の成長発展が基本となるが，一方日本経済の好不況にも左右され る他意的なものでもあるので, これらに加えて S R Eの従来品種 の拡大と新用途, 新品種の開発, 製品の多角化などを一層推進す るとともに, 世界的視野のもとに諸対策を実施することによつて 安定した増産効果を産み出してゆくことになろう。

一方技術的な面でのコストダウンは多面的に逐年実施し成果を あげてきた。一例をいえば電気炉をガス炉に変更した効果はエネ ルギーコストにかなりの寄与をしている。しかし技術的にはまだ改 善によるコストダウンの余地が残つていると思うので, 前述の如 く当面の重点項目としてとりあげューザーへのフィードバックを 果してゆきたい。

製品多角化の一つとして近く三井金属鉱業の炭化物プラントを 当地に発展的に引き継ぐことになろうが，それは単に数量面のみ
ならず, 品種, 品質面を含めてのことであり, 特にこの分野につ いてはユーザーとの緊密な技術的連繫をべースとしての成長が期 待できよう。

\section{4. 結 言}

タンタルおよびニオブの製鍊における S R E の技術, 製品品質 およびュストについては前述のように国際水準を上回ることを自 負しつつさらに今後一段と努力を積み重ねる所存である。しかし ながら需要の急増にともない原料鉱石の需給に若干のアンバラン スが生じたことと, 第一次オイルショックに端を発した資源ナシ ョナリズムの抬頭などが相乗的に作用してタンタル鉱石価格の異 常な急騰をきたした。

ファイナルユーザーは自己防衛対策として技術開発の武器をふ りかざして, 代替品などを利用する脱タンタルの方向を真剣に模 索中のもようである。時間的に遅速の差はあろうが, そしてその 規模の差こそあろうが，その日のいずれくることも間違いないと しても, タンタル, ニオブはその優れた特性によつて, 現在の用 途を含めて新らしい未来を持ち続けることも確かであろう。

したがつて今後は三井金属の鉱山会社としての優れた探査, 採 鉱, 選鉱などの技術のより強力なバックアップのもとに, 自社で 資源をコントロールしてゆくことなども加味して, 国際的な協力 のもとに原料価格をリーズナブルな線にひき戻して, 長期的かつ 安定的にこの事業の発展を計つてゆきたいと思つている。

\title{
Outline of Sankin Rare Earth Co., Ltd. (SRE) and Its Miike Tantalum and Niobium Plant
}

\author{
by Toshio MIURA
}

SRE was established about twenty years ago for producing several compounds of rare earth elements. SRE is one of the subsidiaries of Mitsui Mining and Smelting Co., Ltd. (MMS), which has many plants producing not only base metals such as Cu, $\mathrm{Zn}, \mathrm{Pb}$, and $\mathrm{Al}$, but also many new metals including $\mathrm{Ta}$ and $\mathrm{Nb}$. As part of a long term plan for the development of a new metals division, several years ago MMS transferred the oxide plant, which was one of its Ta and Nb plants, to SRE.

SRE's $\mathrm{Ta}$ and $\mathrm{Nb}$ plant has many improved methods for oxide processing. For example, many kinds of ore concentrates and other scraps containing tantalum raw materials can be fed which are then dissolved in hydrofluoric acid and sulphuric acid in special corrosion-resistant tanks. Liquid-liquid extraction with MIBK is the usual method for Ta-Nb purification; however, SRE's improved process can bring about a higher quality solution both automatically and economically. From the stripped solution, pure tantalum oxide and niobium oxide are produced.

The capacity of SRE's plant has already grown several times as large as what it was before during these past few years. Soon, SRE will have a carbide plant for production of tantalum and other metals in the course of its next step in the transference of production facilities from MMS. After that SRE will be anticipating even further expansions and developments in its future.

\section{〔4-10〕昭和KBI 東長原工場におけるタンタル製錬}

\section{1. 緒言}

当工場は昭和電工(株) と米国カベッキー・ペルリコ・インダス トリーズ・インコーポレーテッド（ＫＢＩと略称す）との合弁会 社で, 昭和47年 3 月に設立された。それ以前は昭和電工の中央研 究所で基礎研究の後, 昭和39年に現在の福島県河沼郡河東町大字

1. 昭和K B I 株式会社東長原工場長代理

2. 昭和KB I 株式会社東長原工場課長補佐

3. 昭和KB I 株式会社東長原工場主務

4. 昭和KB I 株式会社取締役

$$
\begin{array}{lllll}
\text { 小山 恵 二 } & \text { 泉 } & \text { 知 } \text { 夫 }^{2} \\
\text { 水 崎 } \text { 雄二郎 }^{3} & \text { 小 松 昭 } \text { 利 }^{4}
\end{array}
$$

東長原にてパイロットプラントの形でスタートし, 昭和 47 年 3 月 まで昭和電工としてタンタル粉末を製造してきた。

現在は国内唯一のメーカーとして, 客先に対しての供給責任を, 安定した中間原料の供給先を持つていること, および粉末の品質 が優れていることにより,及ばずながらも果たし,ひいては日本の 電子工業の発展のため些少の寄与をしていると自負している。

工場は風光明媚な福島県会津船梯山の簏にある。電子材料とし てのタンタル粉末を製造するため, 特に不純物による污染などの 心配が要らない清澄な雾囲気は当工場の大きな利点の一つである。 
以下製造工程について詳述する。

\section{2. 操業フローシート}

当工場における製造工程のフローシートを第 1 図，第 2 図，第 3 図に示す。

\section{3. 製造工程の説明}

\section{$3 \cdot 1$ 金属 $\mathrm{Na}$ 還元によるタンタル粉末の製造}

電解コンデンサ用のタンタル粉末の具備すべき条件としては, まずコンデンサ陽極素子を成型する際に問題となる流れ性がよい こと，およびその成型体の強度が強いことが必要である。

次にこの素子を真空焼結して強固な構造として，それに酸化皮 膜をつけて, 電解質を入れ, 最終的にヶースへ入れてコンデンサ とするが，このとき酸化皮膜に欠陌があると信頼性が悪くなる。 この欠陥は不純物が存在するとそこに発生するので不純物はなる べく少ない方が望ましい。

次にコンデンサとしての容量は, 素子内部の表面積に比例す るが，これは粉末の細かさに依存するもので高い容量を出すため には細かい粉末が必要である。

金属 $\mathrm{Na}$ 還元によるタンタル粉末は, 一般に民生用と呼ばれる電 気機器たとえばステレオ，テレビなどに使われる電解コンデンサ の素材となるもので, 第 4 図にその走查電䫓写真を示すように, 粒子形状が複雑なので比表面積が大きく, 高容量を出すのでュン デンサが小型化できるのが特徵である。

次に2.の操業フローシートにそつてタンタル粉末製造の各工程 について説明する。

（1）還元工程 $\mathrm{K}_{2} \mathrm{TaF}_{7}$ とナトリウムの基本反応式は次の ように示される。

$$
\mathrm{K}_{2} \mathrm{TaF}_{7}+5 \mathrm{Na}=2 \mathrm{KF}+5 \mathrm{NaF}+\mathrm{Ta}
$$

実際の工程では $\mathrm{K}_{2} \mathrm{TaF}_{7}$ (融点約 $750^{\circ} \mathrm{C}$ ) を溶解して,ナトリウ

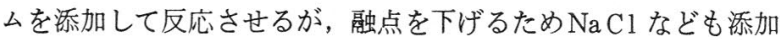
する。電解コンデンサ用としてのタンタル粉末の具備すべき大半 の特性はこの工程で決められる。

粉末の粒子形状は主に粒子の生成する時の温度で決まるが，こ の反応が発熱反応であるため，系の温度管理がむずかしい。

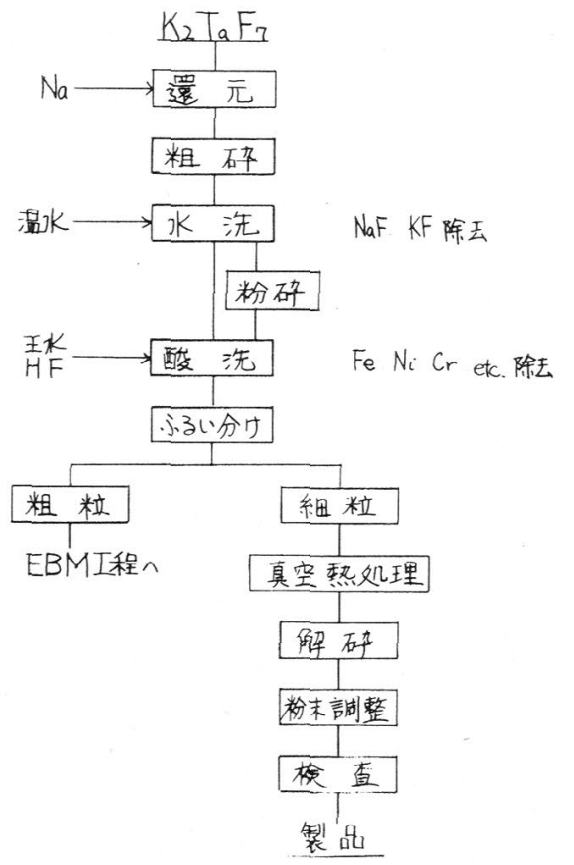

第1図

金属 $\mathrm{Na}$ 還元 による $\mathrm{Ta}$ 粉 末の製造フロ ーシート 粉末
一般的には反応条件は，粉末の電気特性および粉末物性ひいて は客先に扝计る焼結特性等とのバランスを考慮した上での設定が 必要である。

（2）水洗工程還元されたタンタル粉末は反応式にみられ るように，塩との混合物の形でとり出される。これらの塩は，水 にとけやすい性質を利用して除去される。

（3）粉砝工程水洗を終了したタンタル粉末のうち一部分 は，粉碀工程へまわされる。タンタルは軟かい金属なので粉砕し ても微粉化せずに片状粒に変形する。この片状粒をナトリウム還 元粉に混合して用いると, コンデンサの焼結工程での過焼結防止 の有効な手段となる。これは当社の製品における特徵の一つであ る。第 4 図に片状粒の存在が明らかに示されている。

（4）酸洗工程粉砕工程拉よび還元反応材質などからもた らされる $\mathrm{Fe}, \mathrm{Ni} ， \mathrm{Cr}$ などは酸で取り除かれる。水洗および酸洗 工程より発生するガスや排水の処理は, 回収設備, 清浄装置, 沈 殿沪過槽などの環境対策設備により万全の体制が整つている。

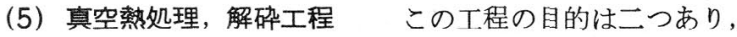
一つはガスの除去であり，もう一つは造粒のための凝集である。

タンタルは酸化しやすいため, $10^{-4} \sim 10^{-5} \mathrm{~T}$ orr 真空中で 加熱される。水素などのガスは $800^{\circ} \mathrm{C}$ 前後でほとんど放出してし まうが，さらに高温に上げて凝集させる。この凝集体を適当な粒 度に解碎する。

（6）粉調工程各製品グレード毎に設定された各特性規格 值と照合して，原料粉を選び，混合して製品口ットへ仕上げてい <。

（7）検查工程 ここでタンタル粉末はコンデンサ用として 使用されるための条件をすべてチェックされる。コンデンサの信頼

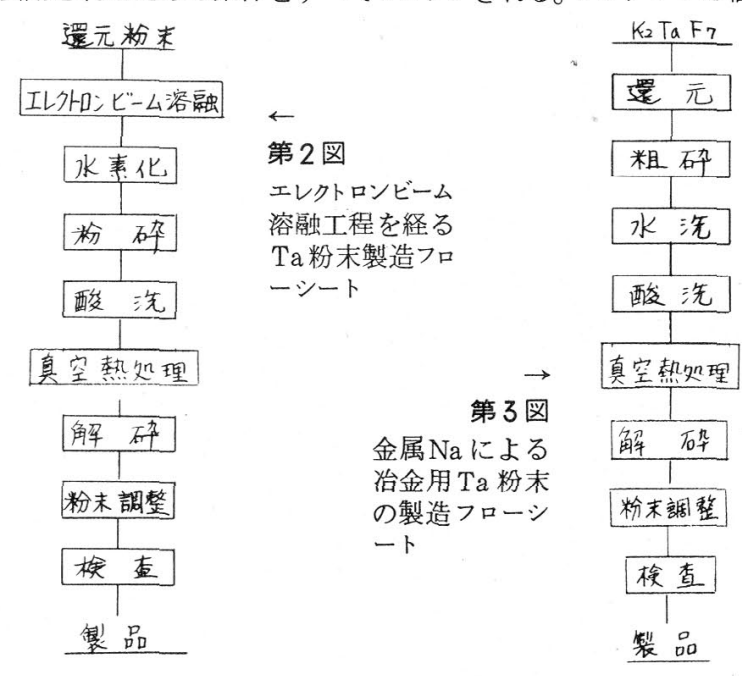

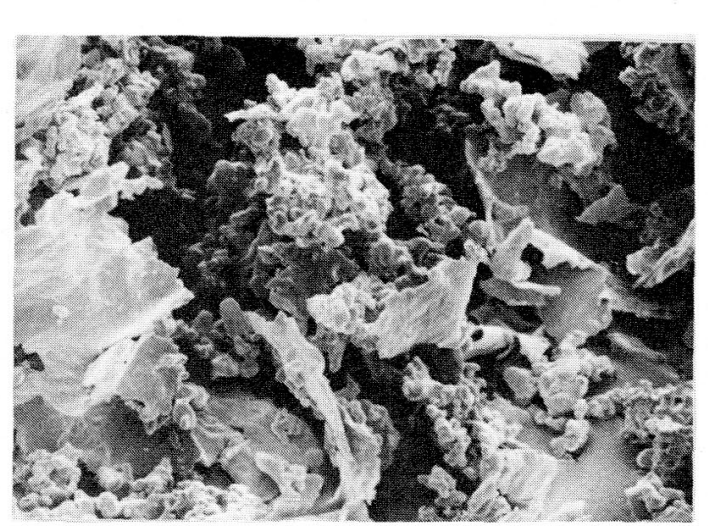

金属ナトリウム 還元によるタン タル粉㧍よびそ の粉砕粉の混合 
性に影響を及ぼす不純物の分析に対しては, ガス分析, 発光分光, 原子吸光などを利用し，未知の成分に対しても常にみのがすこと がないようにしている。

粉末特性としては, 粒度分布, 比表面積, 加密度, 流動性, 成型性などを測定する。

電気的特性としては, 粉末を成型, 焼結した後, 容量, もれ電 流, 電力損失, 耐圧などを唡査する。

\section{$3 \cdot 2$ エレクトロン・ビーム溶瀜工程を経るタンタル粉末の 製造}

一般に産業用電気機器と呼ばれているコンピュータ, 電子交換 機などに使われる高信頼用のコンデンサは, 特に純度が笅しい規 制を受けるために，エレクトロン・ビームによつて精製されたタ ンタルインゴットよりつくられる。第 5 図に示すように金属ナト リウム還元粉とは，粒子の形状が全く異なつている。

次に，2.の操業フローシートにそつて各工程について説明する。

(1) エレクトロン・ピーム溶瀜工程 (EBM之略称) ナト リウム還元粉のうち, ふるい分けで得られた粗粒やE B M 用とし

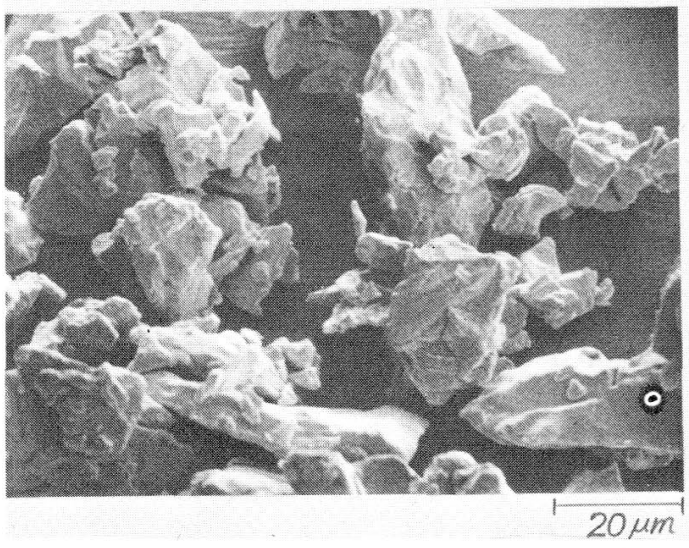

第5図 E B M工程を経たタンタル粉末
て還元されたタンタル粉末は, E B M工程 を経て純度の極めて高いタンタルインゴッ トになる。

（2）水素化工程 タンタルインゴッ トを粉末にするためにタンタルが氷素を吸 蔵してもろくなる性質を利用する。タンタ ルインゴットを水素雾用気のもとで加熱す るとインゴットは水素原子を結晶格子の侵 入型の位置で吸蔵するため, 結晶が昰みを 起こし, 硬くもろくなつて粉碎されやすくな る。ちなみに水素を吸つていないタンタル は，延性に富むためインゴットをそのまま 粉砕するのは不可能である。

（3）粉碎工程水素を吸つてもろく なつたタンタルインゴットは, ジョー・ク ラッシャなどで粗砕した後, 衝撃粉砕機な どで微粉碎される。ここでは粉末の粒度, 粒径などにバラッキがないように管理する とともに，不純物の混入が考えられるので， 雲用気，材質などには特に注意が必要であ る。

（4）酸洗工程粉确された粉末は, 酸洗いされる。

（5）真空熱処理，解砕工程 粉末に 含まれている水素ガスを除去するためと， タンタル粉末の流れ性, 成型性などをよく するために， $10^{-5}$ Torr 台の高真空のも とで熱処理を行なう。

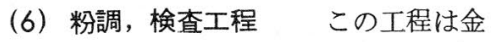
属ナトリウムによるタンタル粉末と同じで あるが，特に不純物は厳しい管理が必要で ある。

\section{$3 \cdot 3$ 冶金用タンタル粉末の製造}

タンタルは電解コンデンサ用の他に, 耐 食用材料，鉄鋼添加材料などにも使用され 一般に冶金用粉末と呼ばれる。当社でも治 金用としてタンタル粉末を製造しているが, この場合は生産性などに相違がある他は， $3 \cdot 1$ で述べたT程と同じである。
第 1 表 コンデンサ用の金属 $\mathrm{Na}$ 還元 $\mathrm{Ta}$ 粉末の粉末物性および不純物値

\begin{tabular}{|c|c|c|c|c|c|c|c|c|}
\hline \multirow{2}{*}{$\begin{array}{l}\text { 製品 } \\
\text { グレード名 }\end{array}$} & \multicolumn{3}{|c|}{ 粉 末 物 性 } & \multicolumn{2}{|r|}{ 不 } & 純 & \multicolumn{2}{|l|}{ 物 } \\
\hline & $\begin{array}{c}\text { かさ密度 } \\
\mathrm{g} / \mathrm{cm}^{3}\end{array}$ & $\begin{array}{r}\text { 平均粒径 } \\
\mu_{\mathrm{m}}\end{array}$ & $\begin{array}{l}\text { 粒度 } \\
-325 \text { mesh }\end{array}$ & $\begin{array}{l}\mathrm{O} \\
\mathrm{ppm}\end{array}$ & $\begin{array}{l}\mathrm{Fe} \\
\mathrm{ppm}\end{array}$ & $\begin{array}{l}\mathrm{Ni} \\
\mathrm{ppm}\end{array}$ & $\begin{array}{l}\mathrm{Cr} \\
\mathrm{ppm}\end{array}$ & $\begin{array}{l}\mathrm{C} \\
\mathrm{ppm}\end{array}$ \\
\hline $\mathrm{DCH}-3$ & 3. 3 & 7. 7 & $<70 \%$ & $<1,400$ & $<30$ & $<20$ & $<5$ & $<40$ \\
\hline DCUH -1 & 2. 9 & 6. 3 & $<55 \%$ & $<1,500$ & $<30$ & $<20$ & $<5$ & $<40$ \\
\hline $\mathrm{DCUH}-2$ & 2. 4 & 4. 9 & $<65 \%$ & $<2,000$ & $<30$ & $<20$ & $<5$ & $<40$ \\
\hline DCUH -3 & 2. 2 & 4. 5 & $<50 \%$ & $<2,300$ & $<30$ & $<20$ & & $<40$ \\
\hline $\mathrm{UH}-5$ & 2. 4 & 4. 0 & $<50 \%$ & $<2,600$ & $<50$ & $<50$ & $<20$ & $<80$ \\
\hline $\mathrm{UH}-6$ & 1. 7 & 3. 3 & $<50 \%$ & $<2,900$ & $<50$ & $<50$ & $<20$ & $<80$ \\
\hline $\mathrm{UH}-7$ & 1. 7 & 3. 3 & $<50 \%$ & $<3,400$ & $<50$ & $<50$ & $<20$ & $<80$ \\
\hline
\end{tabular}

第 2 表 コンデンサ用の金属 $\mathrm{Na}$ 還元 $\mathrm{Ta}$ 粉末の電気的性質

\begin{tabular}{|c|c|c|c|c|c|c|c|}
\hline $\begin{array}{l}\text { 製 品 } \\
\text { グレード名 }\end{array}$ & $\begin{array}{c}\text { 焼結条件 } \\
{ }^{\circ} \times × \min \end{array}$ & $\begin{array}{c}\text { 成形密度 } \\
\mathrm{g} / \mathrm{cm}^{3}\end{array}$ & $\begin{array}{l}\text { ペレット } \\
\text { (重量) }\end{array}$ & $\begin{array}{c}\text { 比 容 量 } \\
\mu \mathrm{FV} / \mathrm{g}\end{array}$ & $\begin{array}{c}\text { もれ電流 } \\
\mu \mathrm{A} / \mathrm{g}\end{array}$ & 電力損失 & $\begin{array}{r}\text { 破壊電压 } \\
\text { V }\end{array}$ \\
\hline $\mathrm{DCH}-3$ & $1,900 \times 30$ & 7. 5 & 1. $6 \mathrm{~g}$ & 3,300 & $<1.0$ & $<14$ & $>270$ \\
\hline DCUH -1 & $1,800 \times 30$ & 7. 0 & $0.3 \mathrm{~g}$ & 4,000 & $<1.5$ & $<7$ & $>270$ \\
\hline DCUH -2 & $1,700 \times 30$ & 7. 0 & $0.3 \mathrm{~g}$ & 5,500 & $<2.0$ & $<15$ & $>250$ \\
\hline DCUH -3 & $1,600 \times 30$ & 7. 0 & $0.3 \mathrm{~g}$ & 7,200 & $<2.5$ & $<15$ & $>250$ \\
\hline DCUH -5 & $1,600 \times 30$ & 6.5 & $0.3 \mathrm{~g}$ & 8,500 & $<3.0$ & $<15$ & $>250$ \\
\hline DCUH -6 & $1,600 \times 30$ & 6.0 & $0.3 \mathrm{~g}$ & 10,000 & $<3.0$ & $<20$ & $>230$ \\
\hline DCUH -7 & $1,600 \times 30$ & 6. 0 & $0.3 \mathrm{~g}$ & 12,000 & $<3.5$ & $<25$ & $>210$ \\
\hline
\end{tabular}

第了表 E B M品タンタル粉末の粉末物性および不純物

\begin{tabular}{|c|c|c|c|c|c|c|c|c|}
\hline \multirow{2}{*}{$\begin{array}{l}\text { 製 品 } \\
\text { グレード名 }\end{array}$} & \multicolumn{3}{|c|}{ 粉 末 物 性 } & \multicolumn{2}{|r|}{ 不 } & 純 & \multicolumn{2}{|l|}{ 物 } \\
\hline & $\begin{array}{c}\text { かさ密度 } \\
\mathrm{g} / \mathrm{cm}^{3}\end{array}$ & $\begin{array}{c}\text { 平均粒径 } \\
\mu \mathrm{m}\end{array}$ & $\begin{array}{l}\text { 粒 度 } \\
-325 \text { mesh }\end{array}$ & $\begin{array}{l}\mathrm{O} \\
\mathrm{ppm}\end{array}$ & $\begin{array}{l}\mathrm{Fe} \\
\mathrm{ppm}\end{array}$ & $\begin{array}{l}\mathrm{Ni} \\
\mathrm{ppm}\end{array}$ & $\begin{array}{l}\mathrm{Cr} \\
\mathrm{ppm}\end{array}$ & $\begin{array}{l}\mathrm{C} \\
\mathrm{ppm}\end{array}$ \\
\hline DCTUL & 6. 0 & 23. 0 & $<60 \%$ & $<800$ & $<10$ & $<10$ & $<5$ & $<30$ \\
\hline DCTL & 4. 4 & 9. 5 & $<85 \%$ & $<1,100$ & $<10$ & $<10$ & $<5$ & $<30$ \\
\hline DCTM & 4. 1 & 6. 6 & $<60 \%$ & $<1,400$ & $<10$ & $<10$ & $<5$ & $<30$ \\
\hline DCTH & 3. 8 & 7. 0 & $<60 \%$ & $<2,000$ & $<10$ & $<10$ & $<5$ & $<30$ \\
\hline DCTH $-\mathrm{S}$ & 3. 8 & 7. 0 & $<60 \%$ & $<2,000$ & $<10$ & $<10$ & $<5$ & $<30$ \\
\hline DCTH $-\mathrm{M}$ & 3. 3 & 7. 0 & $<60 \%$ & $<2,000$ & $<10$ & $<10$ & $<5$ & $<30$ \\
\hline
\end{tabular}

第 4 表 E B M品タンタル粉末の電気特性

\begin{tabular}{|c|c|c|c|c|c|c|c|}
\hline 製 & $\begin{array}{c}\text { 焼結条件 } \\
{ }^{\circ} \mathrm{C} \times \text { min }\end{array}$ & $\begin{array}{c}\text { 成形密度 } \\
\mathrm{g} / \mathrm{cm}^{3}\end{array}$ & $\begin{array}{l}\text { ペレット } \\
\text { (重量) }\end{array}$ & $\begin{array}{c}\text { 比 容 量 } \\
\mu \mathrm{FV} / \mathrm{g}\end{array}$ & $\begin{array}{c}\text { もれ電流 } \\
\mu \mathrm{A} / \mathrm{g}\end{array}$ & 電力損失 & $\begin{array}{r}\text { 破壊電圧 } \\
\text { V }\end{array}$ \\
\hline DCTUL & $2,050 \times 30$ & 9. 0 & 3. $0 \mathrm{~g}$ & $<1,000$ & $<3.0$ & $<$ & $>300$ \\
\hline $\mathrm{DCTL}$ & $2,050 \times 30$ & 9. 0 & 3. $0 \mathrm{~g}$ & $<2,000$ & $<3.0$ & $<12$ & $>300$ \\
\hline $\mathrm{DCTM}$ & $2,050 \times 30$ & 8. 5 & 3. $0 \mathrm{~g}$ & $<2,300$ & $<3.0$ & $<14$ & $>300$ \\
\hline $\mathrm{DCTH}$ & $2,050 \times 30$ & 8. 0 & 3. $0 \mathrm{~g}$ & $<2,700$ & $<3.0$ & $<20$ & $>280$ \\
\hline $\mathrm{DCTH}-\mathrm{S}$ & $1,800 \times 30$ & 7. 5 & 3. $0 \mathrm{~g}$ & $<3,500$ & $<3.0$ & $<20$ & $>250$ \\
\hline DCTH-M & $1,800 \times 30$ & 7. 5 & 3. $0 \mathrm{~g}$ & $<3,500$ & $<3.0$ & $<20$ & $>250$ \\
\hline
\end{tabular}


4. 製品の紹介

$4 \cdot 1$ 金属ナトリウム還元品

第 1 表に当社で製造販売している金属ナトリウム還元によるコ ンデンサ用のタンタル粉末の粉末特性および不純物含有量の典型 的な值を示す。第 2 表には電気的性質として, 信頼性に関するも の（もれ電流，耐圧）, 電力損失㧍よび容量を示す。

これまで述べてきたように，電解コンデンサ用のタンタル粉末 は, 粉末特性, 不純物含有量, 電気的特性の三つの要因のどれ一 つ欠けても使用範用が狭くなつてしまうが，当社の製品はこれら の三つの要因について, 総合的にバランスのとれた優秀な粉末と の評価を得ている。

タンタルコンデンサの特性に対する要求は, 年々ますます厳し くなつてきているが, 特にコンデンサの小型化への要求に応える ために,タンタル粉末の高容量化がなされている。その様子は第 6 図にみられる通りである。

\section{$4 \cdot 2$ EBM品}

第 3 表にE B Mを経た電解コンデンサ用タンタル粉末の粉末特 性および不純物含有量を示す。ここでわかるように E B M工程で の精製効果のため, 不純物のレベルは非常に低くなつている。

\section{$4 \cdot 3$ 冶金用タンタル粉末}

当社では, タンタルインゴット抢よび耐食材料，鉄鋼添加用な どのタンタル粉末を販売している。

\section{5. 终りに}

当社はコンデンサメーカーとの 10 年以上の協力関係により創立 以来品質の向上および新製品の開発に努力してきたが，昭和 50 年

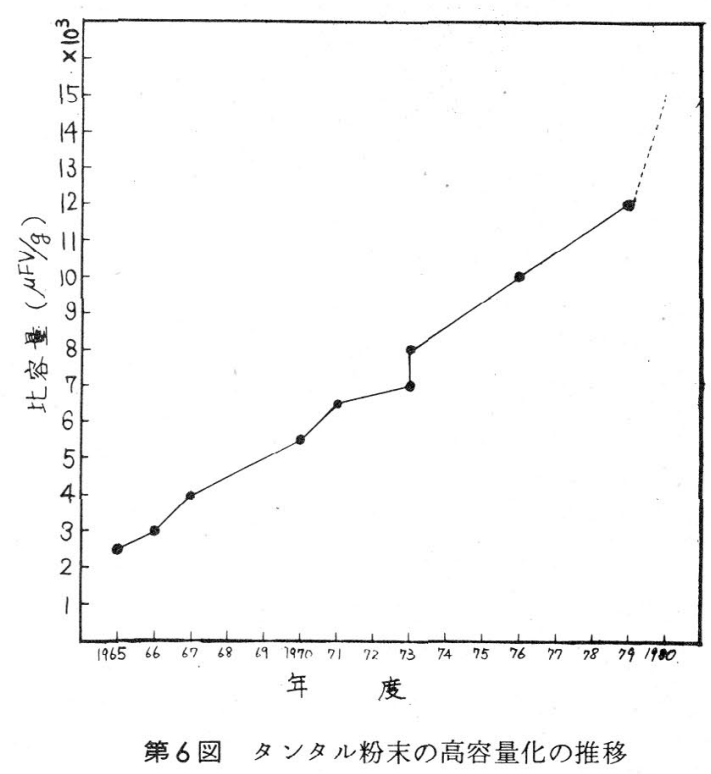

以降は国産唯一のメーカーとして客先の要求に応えて, 当社の製 品の大きな特徵である片状粉の使用などによる超高容量コンデン サ用タンタル粉末を主体にした新グレードの開発に努め成果を上 げてきた。

最近は特に容量増加に対する客先の要求が活発であるが, われ われは今後も信頼性と高容量のバランスのとれたタンタル粉末の 開発をめざすものである。

Processing of Tantalum Metal at Showa-KBI Higashi-nagahara Plant

by Keiji KOYAMA, Tomoo IZUMI, Yujiro MIZUSAKI and Akitoshi KOMATSU

This plant is a joint venture between Kawecki Berylco Industries, Inc., U.S.A. (abbreviated K.B.I.) and Showa Denko K.K. and was established in March, 1972.

\section{[4-11] 日本鉱業 (中央研究所) におけるジルコニウム, ハフニウム製鍊}

\section{小宔 勇 平 $^{1}$}

\section{1. はじめに}

ジルニウム $($ 以下 $\mathrm{Zr}$ ) は熱中性子吸収断面積が 0.18 Barn と 小さく, 高温の水蒸気に対する耐食性に優れて抢り，また機械的 性質，加工性が良いことから合金（主にジルカロイ合金）の形で, BWR, PWRやCANDU型の原子炬に燃料被覆管や構造材とし て使用されている。

当社における $\mathrm{r}$ の製造は, 1957 年に設立された東洋ジルコニ ウム (株)を1964 年に引継いで行なわれ, 現在 (1979年) まで, 第 1 表に示すように原子炬用 $\mathrm{Zr}$ スポンジ約 $600 t$, 一般工業用 $\mathrm{Zr}$ スポンジ約 $250 \mathrm{t}$ を製造し, 国内外に販売している。

原子妒用 $\mathrm{rr}$ スポンジの製造方法について, 原料は一般にジルコ ンサンド $\left(\mathrm{ZrSiO}_{4}\right)$ を使用するが，この鉱石は $\mathrm{Zr}$ とその化学的 性質の類似したハフニウム (以下 Hf) を, Hf / Zr 比にして通常 2

1. 日本鉱業株式会社企画開発本部理事
〜 2.5\%含んでいる。しかしHf は熱中性子吸收断面が Zr の 0.18 Barnに比較して 115 Barn と大きく，このためZrを原子炉材とし

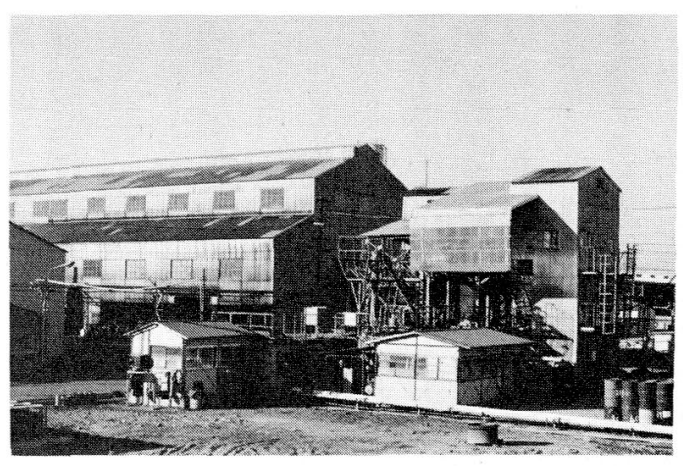

第1図 塩化·還元工場 